Original Research Paper

\title{
Study on Nutritional Value of Instant Sea Cucumber Processed by the New Processing Approach
}

\author{
${ }^{1}$ Shujing Meng, ${ }^{1}$ Huiyan Zhang, ${ }^{1,2}$ Jianfeng Sun and ${ }^{1}$ Qian Liu \\ ${ }^{I}$ College of Food Science and Technology, Agricultural University of Hebei, Baoding 071000, China \\ ${ }^{2}$ Engineering Technology Research Center for Processing of Agricultural Products of Hebei Province, Baoding 071000, China
}

\section{Article history}

Received: 04-01-2017

Revised: $18-02-2017$

Accepted: 28-03-2017

Corresponding Author: Jianfeng Sun

College of Food Science and

Technology, Agricultural

University of Hebei, Baoding

071000, China

Email: causunjf@126.com causunjf@hebau.edu.cn

\begin{abstract}
In this study, the micrograph, the composition of amino acids and fatty acids were analyzed contrastively among the fresh, instant and commercial sea cucumber. The micrographs of fresh, instant and commercial sea cucumbers indicated that the processing technology of instant sea cucumber could effectively inhibit the damage of sea cucumber collagen structure and better maintain its original structure. Depending on the $\mathrm{FAO} / \mathrm{WHO}$ and whole egg model to evaluate the sea cucumber protein's nutritional value, the results showed that instant sea cucumber owned the higher content of amino acid and the perfect profiles of amino acid, which meant that the protein of instant sea cucumber was easily digested and absorbed by human body and belonged to high quality protein. The instant sea cucumber was rich in essential fatty acids and n-3 series of polyunsaturated fatty acids and suitable for the Chinese residents' consumption. This study suggested that the instant sea cucumber was superior to the commercial sea cucumber with effective inhibition of the losing of nutrients and was fit for Chinese residents' consumption as a kind of high-quality products.
\end{abstract}

Keywords: Instant Sea Cucumber, Scanning Electron, Amino Acid, Fatty Acid

\section{Introduction}

Stichopus Japonicus, which belongs to families invertebrates, Echinodermata classes, Hothuridea, is a kind of traditional precious marine product that is well received in the commercial market due to its abundant nutritional value and diet regimen function (Eriksson and Clarke, 2015; Bai et al., 2013; Wen et al., 2010). There are about more than 1100 kinds of recorded species of sea cucumber all over the world (Conand and Byrne, 1993). Sea cucumber is a kind of high quality health seafood with high-protein, low-fat, low-cholesterol and various bioactive constituents (Lawrence et al., 2010; Bordbar et al., 2011; Mamelona et al., 2009), including collagen, acidic polysaccharoses, saponins, cerebroside and so on and the content of collagen and acidic polysaccharoses is higher. Meanwhile, some studies found that these bioactive constituents had numerous functions, such as antitumor, anticoagulation, anti-aging, immunity enhancement, antifungal properties, as well as contributed in blood fat reduction, diabetes control and rheumatoid arthritis prevention and treatment (Bordbar et al., 2011). There is hemolytic enzymes in the body wall of sea cucumber, which lead to the melting of sea cucumber skin when the organism is ecposed at high temperature or encounters certain substances such as oil, minerals or strong oxidants (Qi et al., 2016). Therefore, after captured, the sea cucumber should be processed immediately. The instant sea cucumber product, which can preserve the original flavor and be easy to be eaten and saved, has good market outlook (Toral-Grand et al., 2008). Moreover, may be due to improper processing conditions, such as the cooking temperature, cooking time, the kinds and concentrations of seasoning and the sterilization ways and so on, at present, for commercial sea cucumber products, there are still some problems, such as the nutrition loss and poor sensory quality.

With the speeding up of the life pace and the improvement of people's requirements to the quality of life, the requirement from consumers on the high quality instant food has become more and more urgent (Charunuch et al., 2011).

\section{Materials and Methods}

\section{Materials and Reagents}

All fresh sea cucumbers and commercial sea cucumbers which belong to Stichopus Japonicus were purchased from aquatic product market of Qinhuangdao, 
Heibei Province, China and all fresh sea cucumbers were placed in foam boxes, covered with ice and cold-chain transported to the food laboratory. Seventeen Amino Acids (AA) standard products and twenty mixed fatty acid standard products were purchased from Elydian, America. N-hexane, methanol, acetonitrile and 25\% glutaraldehyde were all of chromatographic grade.

\section{Preparation of Instant Sea Cucumber}

All fresh sea cucumber of uniform quality underwent organ removal through cutting a quarter to a third of the sea cucumber body from the abdomen close to the anus. Afterward, dirt was washed away with distilled water and fresh sea cucumbers were placed into a water bath at 85 to $95^{\circ} \mathrm{C}$ for 2 min to blanch and finalize the design, then the gutted sea cucumbers were put into a $-20^{\circ} \mathrm{C}$ refrigerator to spare. Pretreated sea cucumbers were then boiled (cooking time $17 \mathrm{~min}$, cooking temperature, $83^{\circ} \mathrm{C}$ ) in flavoring liquid (seasoning concentration, $120 \%$. The $100 \%$ seasoning recipe is that the ratio of material to water is $1: 3$ and $1 \mathrm{~kg}$ of the $100 \%$ flavoring liquid contains $35 \mathrm{~g}$ sugar, $5 \mathrm{~g}$ monosodium glutamate, $20 \mathrm{~mL}$ soybean sauce, $20 \mathrm{~g}$ salt, $3 \mathrm{~g}$ ginger powder, $3 \mathrm{~g}$ five-spice powder, $4 \mathrm{~g}$ octagon, $5 \mathrm{~mL}$ white vinegar, 8 $\mathrm{mL}$ cooking wine and $5 \mathrm{~g}$ chicken essence). Then the boiled sea cucumbers were swollen in distilled water. Subsequently, the sea cucumbers were placed into the long neck of a Buchner funnel suction filter and maintained for $30 \mathrm{~s}$ to remove surface moisture, packed with vacuum packing machine (DZ, Aixun Packing Instrument Co Ltd, Shanghai, China) and then sterilized by counter pressure sterilization method (sterilization temperature $103^{\circ} \mathrm{C}$, sterilization time $10 \mathrm{~min}$ ).

\section{Scan Microscopy Analysis}

Fresh, instant and commercial sea cucumber were cut into $0.3 \times 1.0 \times 1.0 \mathrm{~cm}$ tissue blocks and put in $2.5 \%(\mathrm{~m} / \mathrm{m})$ glutaraldehyde butter $(\mathrm{PH}=7.2)$ for one night. Carry out gradient dehydration with 30, 50, 60, 70, 80, 90 and $100 \%(\mathrm{v} / \mathrm{v})$ and replacement with $50 \%(\mathrm{v} / \mathrm{v})$ caproic acid isoamyl acetate acetone solution and pure caproic acid isoamyl acetate on the tissue blocks in turn and then for $\mathrm{CO}_{2}$ critical point drying, ion sputtering metal spraying, scanning electron microscope, respectively.

\section{Detection and Analysis of Amino Acid}

One gram of sea cucumber was hydrolyzed with 10 $\mathrm{mL}$ of $6 \mathrm{M} \mathrm{HCl}$ in a sealed ampoule for $24 \mathrm{~h}$ at $110^{\circ} \mathrm{C}$ under vacuum. The acid hydrolysate was evaporated until dried by using a Speeddvac concentrator (ZLS-1, Hexi instrument machine Co. Ltd, Human, China) and the dry residue was resolved in $2 \mathrm{~mL}$ of $0.1 \mathrm{M} \mathrm{HCl}$. The sample was filtered through a $0.45 \mathrm{~mm}$ nylon filter before being derived (Sujak et al., 2006). Up to $50 \mu \mathrm{L}$ of the sample was added into $200 \mu \mathrm{L}$ of the $\mathrm{Na}_{2} \mathrm{CO}_{3}-$ $\mathrm{NaHCO}_{3}$ solution at $\mathrm{pH} 9.0$ and $100 \mu \mathrm{L}$ of 2,4- dinitrochlorobenzene was added to a water box under a constant temperature of $90^{\circ} \mathrm{C}$. The mixture was maintained for $90 \mathrm{~min}$ without sunlignt. The $\mathrm{pH}$ was adjusted to neutral by adding acetic acid at $25^{\circ} \mathrm{C}$ and then the derivatives were dissolved in $1 \mathrm{~mL}$ of purified water. The sample was filtered through a $0.45 \mathrm{~mm}$ organic filter before being analyzed with HPLC (Kang et al., 2006).

In this study, amino acids were quantified using Waters HPLC system (Water Corporation, Milford, USA). The chromatographic system consisted of a Water 1525 Binary HPLC pump and Waters 2489 UV/Visible detector. Chromatographic separation was performed on an Eclipse $\mathrm{XDB}_{-} \mathrm{C}_{18}$ column $(250 \times 4.6 \mathrm{~mm}, 5 \mu \mathrm{m}$, Adilent Technologies, Palo Alto, USA) with an oven temperature of $40^{\circ} \mathrm{C}$. The detection wavelength was set at $360 \mathrm{~nm}$. The mobile phase involved a mixture solvent (A: Chromatographic grade acetonitrile; B: $2.5 \mathrm{~g}$ of sodium acetate and $1.5 \mathrm{~mL}$ triethylamine dissolved into $1 \mathrm{~L}$ of water, with the solution $\mathrm{pH}$ at 5.25). The flow rate was set at $1 \mathrm{~mL} / \mathrm{min}$. The injection solution volume was set at 10 $\mu \mathrm{L}$ with a Waters 2707 autosampler. Each sample was analyzed thrice and the running time was set at $50 \mathrm{~min}$. The gradient elution program is presented in Table 1 (Cheng et al., 2009).

The protein quality was estimated by determining the Total Amino Acids (TAA), Nonessential Amino Acids (NEAA) and Essential Amino Acids (EAA). According to the FAO/WHO model and the whole egg model (FAO/WHO, 1973), the calculative results of Ratio of Amino Acids (RAA), ratio coefficient of Amino Acids (RC), Ratio coefficient of the Sea Cucumber (SRC) and Essential Amino Acid Index (EAAI) can be used to evaluate the sea cucumber value.

\section{Detection and Analysis of Fatty Acids}

Mash the samples of the sea cucumbers, subsequently, utilizing ultrasonic extraction (ultrasonic power $150 \mathrm{~W}$, ultrasonic voltage $220 \mathrm{~V}$, ultrasonic frequency $40 \mathrm{KHz}$, ultrasonic temperature $45^{\circ} \mathrm{C}$ ), appropriate mashed samples (dry sample $0.50 \mathrm{~g}$, wet sample $5.00 \mathrm{~g}$ ) were extracted for $30 \mathrm{~min}$ with $30 \mathrm{~mL}$ of chloroform-methanol $(2: 1, \mathrm{v} / \mathrm{v})$. This operation was repeated three times and the leaching solution was combined together. Followly, filter the leaching solution and mix the filtrate and $30.00 \mathrm{~mL}$ of KCL solution $(0.9 \%, \mathrm{~m} / \mathrm{v})$ with shock. After $30 \mathrm{~min}$ standing, the chloroform layer was filtered through anhydrous sodium sulfate chromatography column. The fatty acids were obtained by removing the chloroform in the filtrate with rotary evaporation. The fatty acids mixture, which was redissolved with $8 \mathrm{~mL}$ of sulfuric acid-methanol $(10 \%$, $\mathrm{v} / \mathrm{v})$, was methyl esterifyied in $60^{\circ} \mathrm{C}$ water bath for 60 min. After methyl esterification, mix the mixture with 2 $\mathrm{mL}$ of $\mathrm{n}$-hexane and $2 \mathrm{~mL}$ of pure water. After high speed centrifugal $(8000 \mathrm{r} / \mathrm{min}, 20 \mathrm{~min})$, the $\mathrm{n}$-hexane layer was filtered through a $0.45 \mathrm{~mm}$ organic filter before being analyzed with GC-MS. 
Table 1. Gradient elution program

\begin{tabular}{llllllllllll}
\hline Time $(\min )$ & & 0 & 10 & 15 & 30 & 35 & 38 & 42 & 45 & 48 & 49 \\
\hline Eluent & $\mathrm{A} \%$ & 18 & 18 & 20 & 34 & 45 & 55 & 60 & 18 & 18 & 18 \\
& $\mathrm{~B} \%$ & 82 & 82 & 80 & 66 & 55 & 45 & 40 & 82 & 82 & 82 \\
\hline
\end{tabular}

The GC-MS analysis conditions are described as followed. The chromatograph column was $60 \mathrm{~m} \times 0.25 \mathrm{~mm}, 0.25 \mu \mathrm{m}$. The temperature of the injection port was $240^{\circ} \mathrm{C}$. Split model was set up. The split ratio was set at 1:15. The carrier gas $\left(\mathrm{N}_{2}\right)$ flow rate was $1 \mathrm{~mL} / \mathrm{min}$. The programmed oven temperature was: $130^{\circ} \mathrm{C}$ as started, $130-180^{\circ} \mathrm{C}$ at $4^{\circ} \mathrm{C} / \mathrm{min}, 180-240^{\circ} \mathrm{C}$ at $2^{\circ} \mathrm{C} / \mathrm{min}, 240^{\circ} \mathrm{C}$ for $20 \mathrm{~min}$. The ion source, interface and Level $4 \mathrm{rod}$ temperature was 230,250 and $150^{\circ} \mathrm{C}$, respectively. Full scan methods (30-500 amu/s) was adopted.

\section{Statistical Analysis}

The analyses were repeated three times and results were expressed as mean values \pm Standard Deviation (SD) $(n=3)$. All data sets were analyzed statistically by SPSS 17.0 and Analysis of Variance (ANOVA) and Multiple comparison test (Tukey HSD) were adopted.

\section{Results and Discussion}

\section{Scan Microscopy Analysis}

About 200 and 1000 times scanning electron micrographs of fresh, instant and commercial sea cucumber was showed as Fig. 1. As revealed as the result, the collagen fiber of the fresh sea cucumber was finer, the space network structure was abundant, while the instant and commercial sea cucumber's were coarser and had a certain direction. By analyses, the inflation of collagen resulted from high temperature and high pressure may be the reason. Compared with the commercial sea cucumber, the collagen fiber of the instant sea cucumber, which was more similar to that of the raw fresh sea cucumber, was finer, longer and the space network structure was more dense and there was not larger gaps. The results indicates that the processing technology of this study can reduce the change of the collagen fiber and control the assembled shrinkage of the collagen fiber effectively to reduce the losses of the collagen and, finally, we could obtain better quality instant fresh sea cucumber products.

\section{Analysis of Amino Acids Composition}

The protein is abundant in sea cucumber and the collagen accounts for about $70 \%$. This study, by detecting the content of 17 kinds of amino acids in sea cucumber, evaluated the nutritional value of the instant fresh sea cucumber products made by the new process. As shown in Table 2, comparing with the instant sea cucumber, there was 6 kinds of amino acids' content which was not significant different from that of the fresh and 14 kinds of amino acids' content which was more than the commercial's significantly $(p<0.05)$ and the EAA and TAA were more than the commercial's significantly $(p<0.05)$ and compared with the fresh sea cucumber, the EAA and the TAA retention rate of the instant was 88.28 and $93.10 \%$, respectively, which indicates that the processing technology of instant sea cucumber can avoid the losses of the amino acids of sea cucumber effectively. The EAA/TAA recommended by the WHO is $38 \%$ and by the FAO/WHO is about $35 \%$. Observed from Table 2, the EAA/TAA of the fresh sea cucumber is $33-35 \%$ which indicated that the ratio of EAA and TAA of sea cucumber was excellent and the protein was a kind of high quality protein and had high nutritional value. The EAA/TAA of the processed instant sea cucumber was 0.31-0.33, which was not different with the commercial significantly and close to the recommendation. Consequently, the processed instant sea cucumber was a high quality protein product.

According to the recommended model of FAO/WHO and whole egg model, the RAA, RC, SRC and EAAI of the fresh, instant and commercial sea cucumber were calculated and the result was shown as Table 3 and 4 . When the value of RAA and RC were closer to 1 , indicating that the EAA of the product was closer to the model recommendation. When the value was greater than 1, indicating that the EAA was more than the stantard model; When the value was smaller than 1, indicating that the EAA was lower than the stantard model. When SRC and EAAI as evaluation standard, the value was closer to 1 , indicating that the nutrition value of the protein was higher and the probability of absorbed by the body was bigger.

Table 3 showed that the most value of RAA of the fresh, instant and commercial sea cucumber was close to 1 and the instant's generally higher than that of the commercial and closer to 1, which indicated that the amino acids composition of the fresh was better. Compared with the amino acids composition of the commercial, the instant's was closer to the recommend model. Table 4 showed that the SRC of the instant was significantly $(p<0.05)$ higher than that of the fresh and there was no significant difference with the commercial. The reason maybe that, through the high temperature and high pressure, the losses of some amino acids made the ratio of amino acids more reasonable and easier to be absorbed by body. According to evaluation model of $\mathrm{FAO} / \mathrm{WHO}$, the value of EAAI of the fresh was closer to 1 , while that of the instant was significantly $(p<0.05)$ lower than that of the commercial; According to the evaluation model of the whole egg, the value of EAAI of the instant was significantly better than 
that of the commercial, which indicated that, while the whole egg model as the evaluation model, the nutrition value of the instant sea cucumber was higher than that of the commercial.

In conclusion, fresh sea cucumber was a high quality protein resource and not only the instant sea cucumber processed by the new processing technology had higher amino acids retention, but also had more reasonable ratio of amino acid composition and the instant sea cucumber was a kind of high quality seafood meeting the needs of the human body and having high nutrition value of protein.

\section{Analysis of Fatty Acids Composition}

The contents of 19 kinds of fatty acids of the fresh, instant and commercial sea cucumber were showed as
Table 5 and the 11,14,17-Eicosatrienoic acid was not detected, C20:3 what was showed in the table was 8,11,14-Eicosatrienoic acid. As indicated in Table 5, there were abundant oleic acid (C16:1), linoleic acid (C18:3), $\alpha$-Linolenic acid (C18:3), arachidonic acid (C20:4), EPA (C20:5) and DHA (C22:5), which stated that sea cucumber was rich in the human body essential fatty acids and aquatic product characteristic fatty acids which were important to the human body. In instant sea cucumber product, the content of 6 kinds of fatty acids were significantly $(p<0.05)$ higher than that of the commercial and the contents of Monounsaturated Fatty Acids (MUPA) and Polyunsaturated Fatty Acids (PUFA) were also significantly higher than that of the commercial, that indicated that the processing technology can effectively avoid the losses and damage of fatty acids.

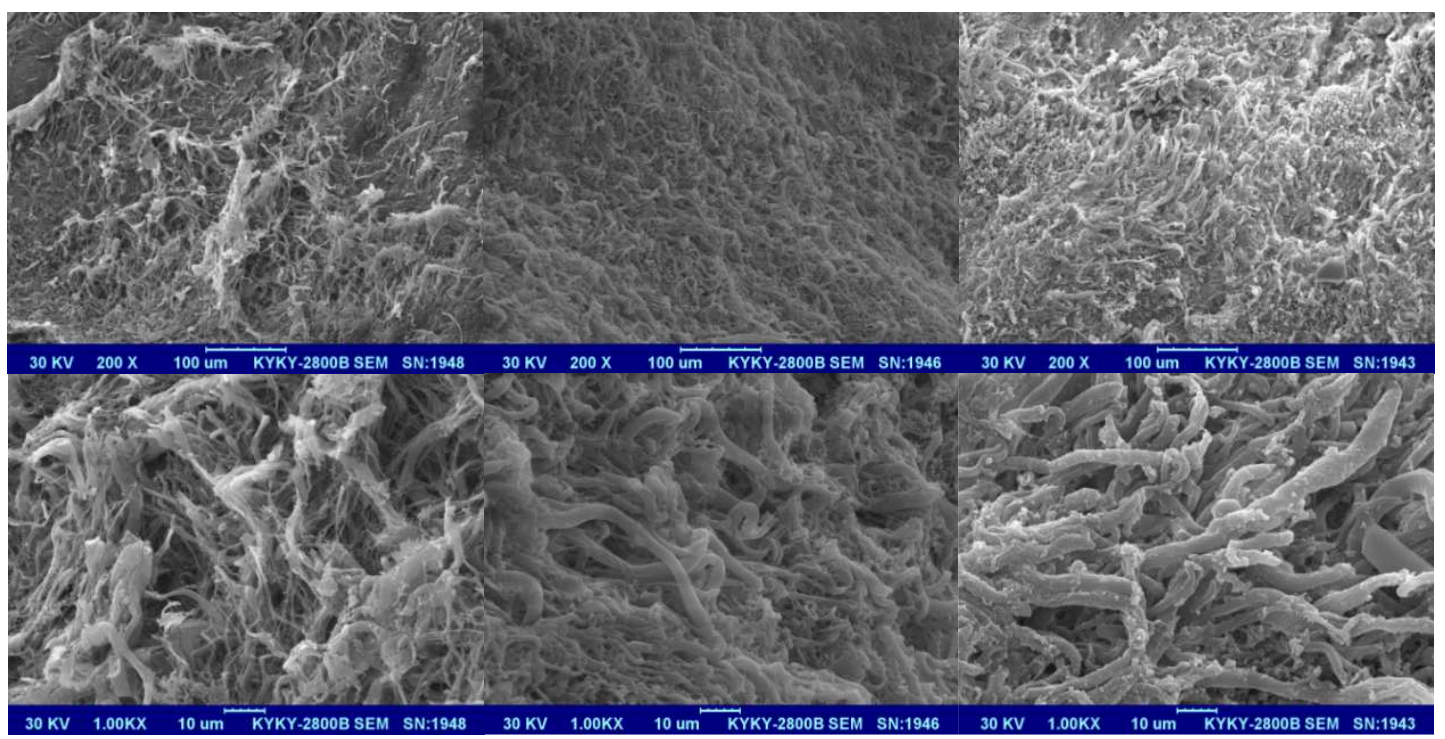

Fig. 1. Scanning electron micrographs of fresh, instant and commerical sea cucumber

Table 2. Amino acid profiles ( $\mathrm{g} / 100 \mathrm{~g}$ Crude Protein) of protein concentrations from fresh, instant and commercial sea cucumber

\begin{tabular}{lllll}
\hline & Amino acids & Fresh & Instant & Commercial \\
\hline & Asp & $10.59 \pm 0.11^{\mathrm{c}}$ & $9.98 \pm 0.10^{\mathrm{b}}$ & $9.20 \pm 0.04^{\mathrm{a}}$ \\
& Glu & $15.71 \pm 0.08^{\mathrm{b}}$ & $15.48 \pm 0.08^{\mathrm{b}}$ & $14.29 \pm 0.19^{\mathrm{a}}$ \\
NEAA & His & $1.42 \pm 0.01^{\mathrm{c}}$ & $1.06 \pm 0.06^{\mathrm{b}}$ & $0.97 \pm 0.02^{\mathrm{a}}$ \\
& Ser & $4.77 \pm 0.12^{\mathrm{b}}$ & $4.74 \pm 0.12^{\mathrm{b}}$ & $4.51 \pm 0.03^{\mathrm{a}}$ \\
& Arg & $8.26 \pm 0.09^{\mathrm{c}}$ & $8.05 \pm 0.06^{\mathrm{b}}$ & $7.58 \pm 0.09^{\mathrm{a}}$ \\
& Gly & $8.73 \pm 0.11^{\mathrm{b}}$ & $8.50 \pm 0.10^{\mathrm{b}}$ & $7.60 \pm 0.09^{\mathrm{a}}$ \\
& Pro & $5.49 \pm 0.11^{\mathrm{b}}$ & $5.30 \pm 0.10^{\mathrm{ab}}$ & $5.12 \pm 0.07^{\mathrm{a}}$ \\
& Ala & $5.95 \pm 0.08^{\mathrm{b}}$ & $5.32 \pm 0.17^{\mathrm{a}}$ & $5.99 \pm 0.21^{\mathrm{b}}$ \\
& Cys & $2.42 \pm 0.08^{\mathrm{c}}$ & $2.15 \pm 0.03^{\mathrm{b}}$ & $1.73 \pm 0.00^{\mathrm{a}}$ \\
& Tau & $0.61 \pm 0.01^{\mathrm{c}}$ & $0.54 \pm 0.03^{\mathrm{b}}$ & $0.40 \pm 0.00^{\mathrm{a}}$ \\
& Val & $4.69 \pm 0.14^{\mathrm{b}}$ & $4.37 \pm 0.11^{\mathrm{b}}$ & $4.17 \pm 0.16^{\mathrm{a}}$ \\
EAA & Met & $2.48 \pm 0.03^{\mathrm{b}}$ & $2.10 \pm 0.06^{\mathrm{a}}$ & $1.97 \pm 0.10^{\mathrm{a}}$ \\
& Thr & $5.39 \pm 0.13^{\mathrm{b}}$ & $5.15 \pm 0.07^{\mathrm{b}}$ & $4.69 \pm 0.09^{\mathrm{a}}$ \\
& Ile & $4.04 \pm 0.07^{\mathrm{c}}$ & $3.57 \pm 0.06^{\mathrm{b}}$ & $3.27 \pm 0.09^{\mathrm{a}}$ \\
& Leu & $5.74 \pm 0.10^{\mathrm{c}}$ & $5.16 \pm 0.05^{\mathrm{b}}$ & $4.71 \pm 0.06^{\mathrm{a}}$ \\
EAA & Phe & $3.75 \pm 0.15^{\mathrm{c}}$ & $3.17 \pm 0.06^{\mathrm{b}}$ & $2.81 \pm 0.07^{\mathrm{a}}$ \\
TAA & Lys & $7.03 \pm 0.18^{\mathrm{c}}$ & $5.73 \pm 0.02^{\mathrm{c}}$ & $4.90 \pm 0.08^{\mathrm{a}}$ \\
EAA/NEAA & & $33.12 \pm 0.62^{\mathrm{c}}$ & $29.24 \pm 0.17^{\mathrm{b}}$ & $26.52 \pm 0.30^{\mathrm{a}}$ \\
EAA/TAA & & $97.07 \pm 0.93^{\mathrm{c}}$ & $90.37 \pm 0.56^{\mathrm{b}}$ & $83.91 \pm 0.55^{\mathrm{a}}$ \\
\hline & & $0.52 \pm 0.01^{\mathrm{b}}$ & $0.48 \pm 0.01^{\mathrm{a}}$ & $0.46 \pm 0.01^{\mathrm{a}}$ \\
& & $0.34 \pm 0.01^{\mathrm{b}}$ & $0.32 \pm 0.01^{\mathrm{ab}}$ & $0.32 \pm 0.00^{\mathrm{a}}$ \\
\hline
\end{tabular}


Shujing Meng et al. / American Journal of Biochemistry and Biotechnology 2017, 13 (1): 51.57 DOI: 10.3844/ajbbsp.2017.51.57

Table 3. RAA and CS of fresh, instant and commercial sea cucumber

\begin{tabular}{|c|c|c|c|c|c|c|c|c|}
\hline \multirow{2}{*}{$\begin{array}{l}\text { Amino } \\
\text { acids }\end{array}$} & \multicolumn{6}{|l|}{ RAA\% } & \multicolumn{2}{|c|}{ Recommended $\mathrm{g} \cdot 100 \mathrm{~g} \mathrm{Pr}^{-1}$} \\
\hline & Fresh & Instant & Commercial & Fresh & Instant & Commercial & $\mathrm{FAO} / \mathrm{WHO}$ & Egg \\
\hline$\overline{T h r}$ & $1.35 \pm 0.03^{b}$ & $1.29 \pm 0.02^{b}$ & $1.17 \pm 0.02^{\mathrm{a}}$ & $1.06 \pm 0.03^{b}$ & $1.01 \pm 0.02^{\mathrm{b}}$ & $0.92 \pm 0.02^{\mathrm{a}}$ & 4.0 & 5.1 \\
\hline Val & $0.94 \pm 0.03^{\mathrm{b}}$ & $0.87 \pm 0.02^{\mathrm{ab}}$ & $0.83 \pm 0.03^{\mathrm{a}}$ & $0.85 \pm 0.03^{\mathrm{b}}$ & $0.79 \pm 0.02^{\mathrm{ab}}$ & $0.76 \pm 0.03^{\mathrm{a}}$ & 5.0 & 7.3 \\
\hline Met + Cys & $1.40 \pm 0.03^{\mathrm{c}}$ & $1.22 \pm 0.01^{\mathrm{b}}$ & $1.06 \pm 0.03^{\mathrm{a}}$ & $0.89 \pm 0.02^{\mathrm{c}}$ & $0.77 \pm 0.01^{\mathrm{b}}$ & $0.67 \pm 0.02^{\mathrm{a}}$ & 3.5 & 5.5 \\
\hline Ile & $1.01 \pm 0.02^{\mathrm{c}}$ & $0.89 \pm 0.01^{\mathrm{b}}$ & $0.82 \pm 0.02^{\mathrm{a}}$ & $0.61 \pm 0.01^{\mathrm{b}}$ & $0.54 \pm 0.01^{\mathrm{a}}$ & $0.50 \pm 0.01^{\mathrm{b}}$ & 4.0 & 6.6 \\
\hline Leu & $0.82 \pm 0.01^{\mathrm{c}}$ & $0.74 \pm 0.01^{\mathrm{b}}$ & $0.67 \pm 0.01^{\mathrm{a}}$ & $0.65 \pm 0.01^{\mathrm{c}}$ & $0.59 \pm 0.01^{\mathrm{b}}$ & $0.54 \pm 0.01^{\mathrm{a}}$ & 7.0 & 8.8 \\
\hline Phe + Tyr & $0.62 \pm 0.02^{\mathrm{c}}$ & $0.53 \pm 0.00^{\mathrm{b}}$ & $0.47 \pm 0.01^{\mathrm{a}}$ & $0.37 \pm 0.01^{\mathrm{b}}$ & $0.32 \pm 0.01^{\mathrm{a}}$ & $0.28 \pm 0.00^{\mathrm{a}}$ & 6.0 & 10.0 \\
\hline Lys & $1.28 \pm 0.03^{\mathrm{c}}$ & $1.04 \pm 0.01^{\mathrm{b}}$ & $0.89 \pm 0.01^{\mathrm{c}}$ & $1.10 \pm 0.03^{\mathrm{c}}$ & $0.89 \pm 0.00^{\mathrm{b}}$ & $0.77 \pm 0.00^{\mathrm{a}}$ & 5.5 & 6.4 \\
\hline
\end{tabular}

Table 4. RC, SRC and EAAI of fresh, instant and commercial sea cucumber

\begin{tabular}{|c|c|c|c|c|c|c|c|}
\hline & \multirow{2}{*}{$\begin{array}{l}\text { Evaluation } \\
\text { index }\end{array}$} & \multicolumn{3}{|c|}{ FAO/WHO model } & \multicolumn{3}{|c|}{ Whole egg model } \\
\hline & & Fresh & Instant & Commercial & Fresh & Instant & Commercial \\
\hline \multirow[t]{9}{*}{$\overline{\mathrm{RC}}$} & Thr & $1.27 \pm 0.03^{\mathrm{b}}$ & $1.06 \pm 0.02^{\mathrm{a}}$ & $1.13 \pm 0.02^{\mathrm{a}}$ & $1.34 \pm 0.03^{b}$ & $1.11 \pm 0.02^{\mathrm{a}}$ & $1.18 \pm 0.02^{\mathrm{a}}$ \\
\hline & Val & $0.88 \pm 0.03^{\mathrm{c}}$ & $0.72 \pm 0.02^{\mathrm{b}}$ & $0.80 \pm 0.03^{\mathrm{a}}$ & $1.08 \pm 0.03^{\mathrm{c}}$ & $0.87 \pm 0.02^{\mathrm{a}}$ & $0.97 \pm 0.04^{\mathrm{b}}$ \\
\hline & Met + Cys & $1.32 \pm 0.03^{\mathrm{b}}$ & $1.00 \pm 0.01^{\mathrm{a}}$ & $1.02 \pm 0.03^{\mathrm{a}}$ & $1.13 \pm 0.02^{b}$ & $0.85 \pm 0.01^{\mathrm{a}}$ & $0.86 \pm 0.02^{\mathrm{a}}$ \\
\hline & Ile & $0.95 \pm 0.02^{\mathrm{b}}$ & $0.74 \pm 0.01^{\mathrm{a}}$ & $0.79 \pm 0.02^{\mathrm{a}}$ & $0.77 \pm 0.01^{\mathrm{c}}$ & $0.59 \pm 0.01^{b}$ & $0.64 \pm 0.02^{\mathrm{a}}$ \\
\hline & Leu & $0.77 \pm 0.01^{\mathrm{c}}$ & $0.61 \pm 0.01^{\mathrm{a}}$ & $0.65 \pm 0.01^{\mathrm{b}}$ & $0.83 \pm 0.01^{\mathrm{c}}$ & $0.64 \pm 0.01^{\mathrm{a}}$ & $0.69 \pm 0.01^{\mathrm{b}}$ \\
\hline & Phe + Tyr & $0.59 \pm 0.02^{\mathrm{b}}$ & $0.44 \pm 0.01^{\mathrm{a}}$ & $0.45 \pm 0.01^{\mathrm{a}}$ & $0.47 \pm 0.02^{\mathrm{b}}$ & $0.35 \pm 0.00^{\mathrm{a}}$ & $0.36 \pm 0.01^{\mathrm{a}}$ \\
\hline & Lys & $1.21 \pm 0.03^{\mathrm{b}}$ & $0.86 \pm 0.00^{\mathrm{a}}$ & $0.86 \pm 0.02^{\mathrm{a}}$ & $1.39 \pm 0.03^{b}$ & $0.98 \pm 0.00^{\mathrm{a}}$ & $0.98 \pm 0.02^{\mathrm{a}}$ \\
\hline & SRC & $0.72 \pm 0.01^{\mathrm{a}}$ & $0.78 \pm 0.00^{\mathrm{b}}$ & $0.78 \pm 0.00^{\mathrm{b}}$ & $0.67 \pm 0.01^{\mathrm{a}}$ & $0.73 \pm 0.00^{\mathrm{b}}$ & $0.74 \pm 0.01^{\mathrm{b}}$ \\
\hline & EAAI & $1.02 \pm 0.02^{\mathrm{c}}$ & $0.84 \pm 0.01^{\mathrm{b}}$ & $0.92 \pm 0.00^{\mathrm{a}}$ & $0.78 \pm 0.01^{\mathrm{c}}$ & $0.70 \pm 0.00^{\mathrm{b}}$ & $0.64 \pm 0.00^{\mathrm{a}}$ \\
\hline
\end{tabular}

Table 5. Fatty acid profile $(\mathrm{mg} / \mathrm{kg})$ of fresh, instant and commercial sea cucumber

\begin{tabular}{|c|c|c|c|}
\hline Fatty acids & Fresh & Instant & Commercial \\
\hline \multicolumn{4}{|l|}{ SFA } \\
\hline $\mathrm{C} 14: 0$ & $26.17 \pm 0.35^{\mathrm{a}}$ & $29.69 \pm 0.43^{\mathrm{c}}$ & $27.00 \pm 0.04^{\mathrm{b}}$ \\
\hline C16:0 & $206.81 \pm 5.39^{\mathrm{a}}$ & $292.54 \pm 2.76^{\mathrm{c}}$ & $252.66 \pm 2.40^{\mathrm{b}}$ \\
\hline C18:0 & $68.47 \pm 3.58^{\mathrm{a}}$ & $158.42 \pm 5.15^{\mathrm{c}}$ & $114.26 \pm 1.89^{b}$ \\
\hline C20:0 & $22.35 \pm 0.45^{\mathrm{a}}$ & $44.46 \pm 0.67^{\mathrm{b}}$ & $24.83 \pm 4.34^{\mathrm{a}}$ \\
\hline $\mathrm{C} 22: 0$ & $18.84 \pm 0.44^{\mathrm{a}}$ & $33.87 \pm 0.71^{\mathrm{c}}$ & $25.44 \pm 1.34^{\mathrm{b}}$ \\
\hline $\mathrm{C} 24: 0$ & $24.99 \pm 0.19^{\mathrm{b}}$ & $49.47 \pm 0.37^{\mathrm{c}}$ & $22.57 \pm 0.63^{\mathrm{a}}$ \\
\hline \multicolumn{4}{|l|}{ MUFA } \\
\hline C14:1 & $28.02 \pm 0.37^{\mathrm{a}}$ & $31.80 \pm 0.46^{\mathrm{c}}$ & $28.91 \pm 0.05^{\mathrm{b}}$ \\
\hline C16:1 & $203.56 \pm 1.08^{\mathrm{a}}$ & $276.36 \pm 1.10^{\mathrm{c}}$ & $249.21 \pm 2.31^{\mathrm{b}}$ \\
\hline C18:1 & $107.58 \pm 3.36^{\mathrm{a}}$ & $295.64 \pm 6.48^{c}$ & $180.83 \pm 8.51^{\mathrm{b}}$ \\
\hline $\mathrm{C} 20: 1$ & $137.28 \pm 0.32^{\mathrm{a}}$ & $231.36 \pm 3.65^{\mathrm{c}}$ & $113.68 \pm 4.56^{\mathrm{b}}$ \\
\hline $\mathrm{C} 22: 1$ & $166.13 \pm 3.70^{b}$ & $173.93 \pm 0.92^{\mathrm{b}}$ & $136.13 \pm 4.41^{\mathrm{a}}$ \\
\hline $\mathrm{C} 24: 1$ & $70.96 \pm 2.11^{\mathrm{a}}$ & $117.60 \pm 0.05^{\mathrm{b}}$ & $71.22 \pm 0.21^{\mathrm{a}}$ \\
\hline \multicolumn{4}{|l|}{ PUFA } \\
\hline C18:2 n-6 & $91.41 \pm 2.80^{\mathrm{a}}$ & $132.68 \pm 1.60^{\mathrm{c}}$ & $110.92 \pm 0.69^{b}$ \\
\hline C18:3 n-3 & $206.55 \pm 0.06^{\mathrm{a}}$ & $251.94 \pm 4.05^{\mathrm{b}}$ & $228.88 \pm 17.07^{\mathrm{ab}}$ \\
\hline$C 20: 2 n-6$ & $26.50 \pm 0.71^{\mathrm{b}}$ & $51.19 \pm 0.27^{\mathrm{c}}$ & $23.75 \pm 0.23^{\mathrm{a}}$ \\
\hline$C 20: 3 n-6$ & $29.78 \pm 0.44^{\mathrm{b}}$ & $48.20 \pm 0.77^{\mathrm{c}}$ & $25.92 \pm 0.56^{\mathrm{a}}$ \\
\hline C20:4 n-6(AA) & $299.64 \pm 6.99^{\mathrm{a}}$ & $388.72 \pm 7.09^{c}$ & $339.23 \pm 3.76^{\mathrm{b}}$ \\
\hline C20:5 n-3(EPA) & $259.54 \pm 3.98^{\mathrm{a}}$ & $345.67 \pm 6.75^{c}$ & $314.48 \pm 13.81^{\mathrm{b}}$ \\
\hline C22:6 n-3(DHA) & $162.41 \pm 0.48^{\mathrm{a}}$ & $217.33 \pm 0.49^{c}$ & $190.18 \pm 0.13^{\mathrm{b}}$ \\
\hline SFA & $367.63 \pm 7.53^{\mathrm{a}}$ & $608.45 \pm 7.55^{\mathrm{c}}$ & $466.77 \pm 6.79^{b}$ \\
\hline MUFA & $713.52 \pm 7.22^{\mathrm{a}}$ & $1126.68 \pm 7.67^{\mathrm{c}}$ & $779.97 \pm 3.62^{b}$ \\
\hline PUFA & $1075.82 \pm 9.23^{\mathrm{a}}$ & $1435.73 \pm 15.25^{\mathrm{c}}$ & $1233.36 \pm 8.71^{\mathrm{b}}$ \\
\hline SUM & $2156.98 \pm 17.97^{\mathrm{a}}$ & $3170.86 \pm 9.28^{c}$ & $2480.10 \pm 10.56^{\mathrm{b}}$ \\
\hline$n-3$ & $628.50 \pm 4.28^{\mathrm{a}}$ & $814.95 \pm 9.14^{\mathrm{c}}$ & $733.54 \pm 5.23^{\mathrm{b}}$ \\
\hline$n-6$ & $447.33 \pm 5.83^{\mathrm{a}}$ & $620.78 \pm 8.12^{\mathrm{c}}$ & $499.81 \pm 3.87^{\mathrm{b}}$ \\
\hline$n-3 / n-6$ & $1.41 \pm 0.01^{\mathrm{b}}$ & $1.31 \pm 0.02^{\mathrm{a}}$ & $1.47 \pm 0.01^{\mathrm{c}}$ \\
\hline
\end{tabular}

Studies have pointed out that, in the daily diet, the intake ratio of n-3 and n-6 fatty acids can generate important influence to the health of the body, consequently, the research of n-3/n-6 fatty acids ratio 
was extremely (Li et al., 2015). The recommended intake ratio of $n-3 / n-6$ by Chinese Society of Nutrition was $1: 4-6$ and $1: 4$ by Japan. By investigating, the $n-3 / n-6$ fatty acid intake ratio of Chinese population over the past ten years has exceeded 1:10, meanwhile, the excessive accumulation of n-6 fatty acids and unbalanced n-3/n-6 fatty acids intake ratio would result in disease in aspects of cardiovascular, metabolism and spirit. The results of this study stated that the $n-3 / n-6$ fatty acids ratio of the fresh sea cucumber was $1: 1.41$, which indicated that there was abundant n-3 series of fatty acids in the raw material of sea cucumber; The n-3/n- 6 fatty acids intake ratio of the instant and commercial sea cucumber was 1.31-1.47, which indicated that n-3 series of fatty acids was well preserved. Because of the excessive intake of n-6 series of fatty acids in Chinese residents diet, strengthening the intake of n-3 series of PUFA and reducing the intake of $n-6$ series of PUFA were conducive to health. The $n-3 / n-6$ fatty acids ratio of sea cucumber product was high, so proper intake of sea cucumber product was good for improving the residents' dietary nutrition. In conclusion, although there were less fatty acids in sea cucumber, the essential fatty acids and n-3 series of fatty acids was abundant and the sea cucumber was a better source of fatty acids.

\section{Conclusion}

The micrograph the instant sea cucumber products indicated that the new processing technology of this study can inhibit the assembled shrinkage of the collagen fiber effectively and contain the original structure better; Based on the FAO/WHO model and whole egg model, evaluation results indicated the instant sea cucumber was rich in A variety of amino acids and the ratio of amino acids was reasonable and the instant sea cucumber, which could be absorbed by the body easily, was a high quality source of protein. The instant sea cucumber, which was suitable for Chinese residents' consumption, was rich in the essential fatty acids and n-3 series of fatty acids. The comparative study among the instant, fresh, commercial sea cucumber showed that the processing technology of the instant sea cucumber can better preserve the nutrition value of sea cucumber and the quality of the product was better than that of commercial sea cucumber.

\section{Acknowledgement}

This work was supported by Science and Technology Project of Hebei Province (No. 14273205D), Education Department of Hebei Province (No.YQ2014037), the 'Double First-rate subject-Food Science and Engineering' Program of Heibei Province (2016SPGCA18) and the Program of Young and Top Talents of Hebei Province. The authors declare that they have no competing financial interests.

\section{Author's Contributions}

Shujing Meng and Huiyan Zhang: Involved in sample preparation, performing in the laboratory work and writing the draft.

Jianfeng Sun: Involved in study design, manuscript writing and revising and scientific discussion.

Qian Liu: Involved in nutritional evaluation study.

\section{Ethics}

The authors declare that they have no conflict of interest. All authors have read and approved the manuscript and no ethical issues involved.

\section{References}

Bai, Y.X., M. Qu, Z.Q. Luan, X. Li and Y. Yang, 2013. Electrohydrodynamic drying of sea cucumber (Stichopus japonicus). LWT-Food Sci. Technol., 54: 570-576. DOI: 10.1016/j.lwt.2013.06.026

Bordbar, S., F. Anwar and N. Saari, 2011. High-value components and bioactives from sea cucumbers for functional foods - a review. Marine Drugs, 9: 1762-1805. DOI: 10.3390/md9101761

Charunuch, C., N. Limsangouan, W. Prasert and P. Butsuwan, 2011. Optimization of extrusion conditions for functional ready-to-eat breakfast cereal. Food Sci. Technol. Res., 17: 415-422. DOI: $10.3136 /$ fstr. 17.415

Cheng, J.Y., F. Feng and B.Y. Zhuang, 2009. Development of a new pre-derivatization lc method for analysis of branched-chain and aromatic amino acids in rat plasma and to monitor their dynamic variation as a result of acute hepatic injury. Chromatographia, 70: 57-65. DOI: $10.1365 / \mathrm{s} 10337-009-1110-3$

Conand, C. and M. Byrne, 1993. A review of recent developments in the world sea cucumber fisheries. Marine Fisher. Rev., 55: 1-42.

Eriksson, H. and S. Clrke, 2015. Chinese market responses to overexploitation of sharks and sea cucumbers. Biol. Conservat., 184: 163-173. DOI: $10.1016 /$ j.biocon.2015.01.018

FAO/WHO, 1973. Energy and protein requirements[R]. WHO, Geneva.

Kang, X.J., J. Xiao, X. Huang and Z. Gu, 2006. Optimization of dansyl derivatization and chromatographic conditions in the determination of neuroactive amino acids of biological samples. Clinica Chimica Acta, 366: 352-356. DOI: 10.1016/j.cca.2005.11.011

Lawrence, A.J., R. Afifi, M. Ahmed, S. Khalifa and T. Paget, 2010. Bioactivity as an options value of sea cucumbers in the egyptian red sea. Conservat. Biol., 24: 217-225.

DOI: $10.1111 / \mathrm{j} .1523-1739.2009 .01294 . \mathrm{x}$ 
Li, F.N., Y.H. Duan, Y.H. Li and Y. Tang, 2015. Effects of dietary n-6:n-3 PUFA ratio on fatty acid composition, free amino acid profile and gene expression of transporters in finishing pigs. British J. Nutrit., 113: 739-748. DOI: $10.1017 /$ S0007114514004346

Mamelona, J., R. Saint-Louis and E. Pelletier, 2009. Nutritional composition and antioxidant properties of protein hydrolysates prepared from echinoderm. Int. J. Food Sci. Technol., 45: 147-154. DOI: $10.1111 / \mathrm{j} .1365-2621.2009 .02114 . \mathrm{x}$

Qi, H., H. Fu, X.F. Dong, D.D. Feng and N. Li et al., 2016. Apoptosis induction is involved in UVAinduced autolysis in sea cucumber Stichopus japonicus. J. Photochem. Photobiol., B: Biol., 158: 130-135. DOI: 10.1016/j.jphotobiol.2016.02.034
Sujak, A., A. Kotlarz and W. Strobel, 2006. Compositional and nutritional evaluation of several lupin seeds. Food Chem., 98: 711-719. DOI: 10.1016/j.foodchem.2005.06.036

Toral-Grand, V., A. Lovatelli and M. Vasconcellos, 2008. Sea cucumber: A global review of fisheries and trade. SPC Beche de Mer Inform. Bull., 516: 4-6.

Wen, J., C.Q. Hu and S.G. Fan, 2010. Chemical composition and nutritional quality of sea cucumbers. J. Sci. Food Agric., 90: 2469-2474. DOI: $10.1002 /$ jsfa.4108 